Research Paper

\title{
Improvement of Animal Feed Additives of Ginkgo Leaves through Solid-state Fermentation using Aspergillus niger
}

\author{
Jiahong Wang ${ }^{1,2,3}$, Fuliang Cao ${ }^{2}$, Erzheng Su1,2, Linguo Zhao ${ }^{2}$, Wensheng Qin ${ }^{3 凶}$ \\ 1. College of Light Industry and Food Engineering, Nanjing Forestry University, Nanjing, 210037, China. \\ 2. Co-innovation Center for the Sustainable Forestry in Southern China, Nanjing Forestry University, Nanjing, 210037, China. \\ 3. Department of Biology, Lakehead University, Ontario, P7B 5E1, Canada.
}

$\square$ Corresponding authors: Fuliang Cao: Tel.: +86 25 85427099, E-mail: fuliangcaonjfu@163.com, Address: Nanjing Forestry University, Nanjing, 210037, Jiangsu, China and Wensheng Qin: Tel.: +1 807 3438467, E-mail: wqin@lakeheadu.ca, Address: Lakehead University, Thunder Bay, P7B 5E1, Ontario, Canada.

(c) Ivyspring International Publisher. This is an open access article distributed under the terms of the Creative Commons Attribution (CC BY-NC) license (https://creativecommons.org/licenses/by-nc/4.0/). See http://ivyspring.com/terms for full terms and conditions.

Received: 2017.12.23; Accepted: 2018.03.29; Published: 2018.05.12

\begin{abstract}
To improve the quality of Ginkgo biloba leaves as biological feed additives, twelve Aspergillus niger strains were evaluated for their growth in the moisture ginkgo leaf meal media through solid-state fermentation. The results relating to flavor, flavonoids, enzymes, crude protein, and reducing sugars showed A. niger Gyx086 strain was capable of efficiently fermenting ginkgo leaves. The optimal cultural conditions were three loops of spores inoculation to every $75 \mathrm{~g}$ medium containing $60 \%$ water, grew at $28^{\circ} \mathrm{C}$ for $48 \mathrm{~h}$. The Gyx086 grew well in the medium. The fermented leaves generated a strong sweet-smelling odor, could be identified by electronic nose equipment using a cluster analysis, other than the original offensive smell from non-fermented ginkgo leaves. Each gram dried culture with Gyx086 showed $2.83 \times 10^{9} \mathrm{CFU}$ of A. niger; $3.19 \pm 0.37 \mathrm{FPU}$ of acid-resistant filter paper activity. Its total contents of flavonoids, reducing sugars, and crude proteins were $19.95 \pm 0.23$ $\mathrm{mg}, 24.28 \pm 2.35 \mathrm{mg}$, and $162.81 \pm 3.46 \mathrm{mg}$ in each gram of leaves, $26.03 \%, 62.73 \%$, and $14.58 \%$ higher than the controls, respectively. The essential amino acids and total amino acids contents were $96.41 \%$ and $16.49 \%$ higher than the controls.
\end{abstract}

Key words: Aspergillus niger; Ginkgo biloba leaves; Solid-state fermentation; Biological feed additive; Filter paper activity; Flavonoids

\section{Introduction}

Ginkgo biloba (G. biloba) is a well-known functional plant that has grown on Earth for 300 million years [1]. The components of ginkgo leaves (GLs) include terpenes, polyphenols, organic acids, carbohydrates, esters, mineral salts, and amino acids, among others $[2,3]$. G. biloba extract (EGb) contains substances with extensive biological activity, such as antioxidant [4-6], anticancer [7, 8], anti-mutation [9], and antianxiety $[10,11]$ effects, as well as substance that display curative outcomes for thrombus [12-14], diabetes [15], ulcers [16, 17], epilepsy [18], and Alzheimer's disease [19, 20].

With the scaling-up of ginkgo cultivation and the corresponding price decrease in recent years, the use of GLs as a functional feed additive has expanded for improving livestock and poultry products. Ginkgo leaf powder contains some other beneficial components, such as approximately $12 \%$ protein content, and is being used as an additive in animal feed. However, a fermentation step is necessary before being fed to animals, without fermentation, the powder has a terrible odor and a bitter taste. Nonetheless, studies have shown that EGb can help to improve both the feed conversion rate and production performance of broiler chickens [21] as well as to enhance broiler chicken immunity [22, 23]. A few animal tests have been conducted that indicated GLs fermented by $A$. niger could improve broilers' growth 
performance [24], reduce the feed: gain ratio [25], improve egg quality in laying hens [26], and benefit the immune function of weaned piglets [27]. Moreover, the fermented additive can increase duodenal villous height and crypt depth of birds compared to the control of non-fermented leaves [24]. However, it is not clear why the FGLs bring better benefit than unfermented GLs and there is little literature focusing on the processing program provides suggestions for the feed production.

Solid-state fermentation (SSF) is most suitable for filamentous fungi growth under low-moisture conditions and is a cost-effective technology for the production of bioproducts [28]; thus, SSF appears appropriate for fermenting GLs with A. niger. Unfortunately, GLs contain significant anti-microbial components such as flavonoids and polyphenols with antibacterial or antifungal activity [29-31] that inhibits/delays the growth of microorganisms. Some additives have been supplied in the medium to support microbial growth [24-26], however, these additives raise production costs and reduce production efficiency. Therefore, it is critical to screen the strains considered for fermenting GLs: not only should the strain have a strong fermentation capacity in the GL medium, but the fermented product should also have higher feed quality [32]. The present study focused on studying $A$. niger strains in order to produce a GL bio-feed additive, using moisture GLs as the medium without any additive. Results related to fungal growth and bioproduct quality indicated that the Gyx086 strain is highly suitable for producing a GL biological feed additive.

\section{Materials and Methods}

\section{G. biloba leaves}

The G. biloba leaves were purchased in Pizhou City, Jiangsu Province, China. Leaves had been dried by hot air with a temperature less than $60{ }^{\circ} \mathrm{C}$ via a commercial production procedure. The dried leaves were ground into powder and sieved through a 0.71 $\mathrm{mm}$ screen. The dried leaves contain $8.9 \%$ of water determined by a MA35m-00023V1 analyzer (Sartorius, Germany).

\section{Strains}

Twelve strains of $A$. niger were used in this study. Seven of them, namely Gyx003, Gyx017, Gyx027, Gyx031, Gyx086, Gyx091, and Gyx105 were identified as $A$. niger or $A$. niger var. awamori, selected out of 76 fungal isolates originally obtained from soil samples under an ancient ginkgo tree in our previous study [32]. The other five A. niger strains, XA-8, XA-10, Tu-A, Tu-B, and Tu-C, were stored in our lab. These strains did not produce ochratoxin $A$ toxin in fermented ginkgo leaves (FGLs).

\section{Fungi amplification}

Rose Bengal agar medium (Shengsi, China) was used as an amplification medium. $0.3 \mathrm{ml}$ of dense conidium suspension was applied to the surface in a $10 \mathrm{~cm}$ petri dish using sterile glass bar. The conidium suspension was prepared by washing a plate incubated for four days at $28{ }^{\circ} \mathrm{C}$ with $20.0 \mathrm{ml}$ sterile water. The conidia suspension was homogenized on a vortex mixer (XW-80A, China) for $15 \mathrm{~s}$ before inoculation. Then the plate incubated at $28{ }^{\circ} \mathrm{C}$ for 4 days was inoculated with a metal loop of $0.5 \mathrm{~cm}$ diameter.

\section{Culture preparation and GL SSF}

The leaf powder and water were mixed with a shred to water mass ratio of 5:6 in the strain screening experiment. The mixture was divided into 39 of 250 $\mathrm{ml}$ triangular flasks with $65 \mathrm{~g}$ of the mixture in each bottle, consuming about $40 \%$ of each bottle's volume. With hydrophobic fluoropore membranes (Tianke, China) covering the bottles, the cultures were sterilized at $115{ }^{\circ} \mathrm{C}$ for $15 \mathrm{~min}$. Each bottle was inoculated with three loops of mycelium and thus triplicates for each fungal strain. The flask was inverted ten times to spread the spores and was then cultivated at $26{ }^{\circ} \mathrm{C}$ for seven days. The SSF samples were freeze-dried for analysis. For the humidity ratio experiment of Gyx086, each bottle contained $30 \mathrm{~g}$ in dry weight $(\mathrm{dw})$ of GL powder but different water ratio to ensure uniform volume in each bottle.

\section{Extraction and assay of flavonoids}

The extraction and assay method for flavonoids was implemented according to Wang's description [32]. In brief, $10.0 \mathrm{~g}$ GL sample was immersed in 100 $\mathrm{ml}$ of $70 \%(\mathrm{v} / \mathrm{v})$ ethanol, and an optimized ultrasonic-assisted program was carried out for 45 min at $60{ }^{\circ} \mathrm{C}$ using $100 \mathrm{~W}$ of power at $25 \mathrm{kHz}$. After filtration, the filtrate was extracted one more time. Twice-filtered liquids were combined for determining flavonoids. Total flavonoids assay: $0.5 \mathrm{ml}$ of the extract or the quercetin standard solution was mixed with $3.0 \mathrm{ml}$ of methanol, $0.2 \mathrm{ml}$ of $10 \%$ aluminum chloride (distilled water in blank control), $0.2 \mathrm{ml}$ of 1 $\mathrm{M}$ potassium acetate, and $5.6 \mathrm{ml}$ of distilled water. After $30 \mathrm{~min}$ of incubation, the absorbance was determined at $415 \mathrm{~nm}$ against a distilled water blank using a UV mini-1240 spectrophotometer (Shimadzu, Japan). Triplicates for each sample and the total flavonoid content are expressed as milligrams of quercetin equivalents per gram of dry weight. The flavonol aglycone assay was carried out using the Waters HPLC 2695 System (Waters, USA) with a Waters XBridge C18 column $(5 \mathrm{~mm}, 150 \mathrm{~mm} \times 4.6$ 
mm) and 2489 UA detector. The HPLC column temperature was $40{ }^{\circ} \mathrm{C}$ with a wavelength determined at $370 \mathrm{~nm} .45 \%$ of mobile phase A (1\% phosphoric acid solution) and $55 \%$ of mobile phase B (methanol) were run for 30 min with a constant flow rate of 0.8 $\mathrm{ml} / \mathrm{min}$. The standards of quercetin, kaempferol, and isorhamnetin (Generay Biotech Co., Ltd., China) were used for making a standard curve.

\section{Filter paper activity (FPA) and reducing sugar assay}

A filter paper assay was followed the Chinese National Standard GB/T 23881-2009 [33]. In brief, 5.0 $\mathrm{g}$ of FGLs or unfermented GLs were extracted with $100 \mathrm{ml}$ of citrate buffer ( $0.05 \mathrm{~mol} / \mathrm{l}, \mathrm{pH} 5.5)$, mixed for $30 \mathrm{~min}$ at room temperature and incubated for $24 \mathrm{~h}$ at $4{ }^{\circ} \mathrm{C}$. The filtered liquid was used as an enzyme sample. A $25 \mathrm{ml}$ test tube with $50 \mathrm{mg}$ "Shuangquan" quantitative paper (Xinhua Paper Industry Co., Ltd., China), $1.0 \mathrm{ml}$ of citrate buffer, and $0.5 \mathrm{ml}$ of the diluted enzyme $(0.04-0.18 \mathrm{U} / \mathrm{ml})$ was incubated at 37 ${ }^{\circ} \mathrm{C}$ for $60 \mathrm{~min}$. The reducing sugar content was estimated using the DNS method [34]. One unit of FPA is defined as the amount of enzyme required to release $1 \mu \mathrm{mol}$ of reducing sugar per min.

\section{Assessment of the quality of fermented ginkgo leaves}

A weighted mean was used for evaluating the dominant strain of $A$. niger according to both to fungal growth rates and to the quality of fermented GLs. The evaluation indicator included growth rate, flavor intension, FPA, flavonoid content, protein, and reducing sugar, weighted $15 \%, 20 \%, 20 \%, 20 \%, 15$ $\%$, and $10 \%$, respectively. Each index was graded from one to ten points, with the unfermented GLs (the control) defined as one, the best result defined as ten, and any value less than the control as zero. The total score of each sample was the sum of all indices with the graded value multiplied by the weight and the result expressed in a hundred-mark system.

\section{Smell and aroma character assay}

The smell experiment was carried out by a team of eight assessors using a sensory analysis ranking method $[35,36]$. Briefly, each FGLs and unfermented GLs sample was marked by a three-digit number for sensory analysis. All samples were randomly placed on a white plate. The assessor smelled the odors one by one and described the features and intensity of the sample odor under the marked number. The experimental data were analyzed by a sensory analysis ranking method. For the aroma character assay, an electronic nose instrument (Alpha FOX 3000, Germany) was used to analyze the flavor characteristics. The apparatus is equipped with 12 electronic sensors with a special probing sensibility to different kinds of chemical compounds (Table 1). $120 \mathrm{~s}$ of response data were collected for each sample, then a flavor radar map and cluster analysis program (PCA) were constructed and plotted by the instrumentation procedure.

Table 1. Sensor and sensitive volatile chemical to the sensor.

\begin{tabular}{lll}
\hline Code & $\begin{array}{l}\text { Sensor name designated } \\
\text { by Alpha M.O.S }\end{array}$ & $\begin{array}{l}\text { Sensitive chemical volatile substance } \\
\text { indicated by Alpha M.O.S }\end{array}$ \\
\hline 1 & LY2/LG & Chlorine, fluorine, oxynitride, sulfide \\
2 & LY2/G & Ammonia, amines, carbon oxide \\
3 & LY2/AA & Ethanol, acetone, ammonia \\
4 & LY2/GH & Ammonia, amines \\
5 & LY2/gCTL & hydrogen sulfide \\
6 & LY2/gCT & Propane, butane \\
7 & T30/1 & polar compound, hydrogen sulfide \\
8 & P10/1 & $\begin{array}{l}\text { Nonpolar: hydrocarbon, ammonia, } \\
\text { chlorine }\end{array}$ \\
9 & P10/2 & nonpolar: methane, ethane \\
10 & P40/1 & Chlorine, fluorine \\
11 & T70/2 & Methylbenzene, xylene, carbon monoxide \\
12 & PA/2 & Ethanol, ammonium hydroxide, amines \\
\hline
\end{tabular}

\section{Protein and amino acid assay}

Total crude protein was assessed according to the Kjeldahl method [37] using a set of Gerhardt Kjeldahl determination devices (Buchi, Switzerland). In brief, $1.0 \mathrm{~g}$ of GLs with $0.15 \mathrm{~g} \mathrm{CuSO}_{4}, 4.5 \mathrm{~g} \mathrm{~K}_{2} \mathrm{SO}_{4}$, and $15.0 \mathrm{ml}$ of concentrated sulfuric acid were digested in a K-438 digestive tube at $200^{\circ} \mathrm{C}$ for $30 \mathrm{~min}$; the temperature was then raised to $400{ }^{\circ} \mathrm{C}$ until the liquid became light green. Then using a K-350 distilling apparatus, $200 \mathrm{ml}$ of liquid was collected according to instrument instructions and titrated with $0.05 \mathrm{~mol} / \mathrm{L}$ hydrochloric acid solution to light red with phenolphthalein as the endpoint indicator. The usage amount of hydrochloric acid was calculated and the content of crude protein was expressed as per centum. Three duplicates for each sample were performed.

Free and total amino acids were analyzed using an S433D automatic amino acid analyzer (Sykam, Germany). In brief, extraction was carried out by boiling $2.0 \mathrm{~g}$ of GLs were extracted by boiling them three times for $20 \mathrm{~min}$ with $100 \mathrm{ml}$ of $75 \%$ ethanol solution in a $250 \mathrm{ml}$ conical flask. The filtrates were combined and ethanol was removed by evaporation. The residuum was transferred into a $25 \mathrm{ml}$ volumetric flask in divided doses used $0.02 \mathrm{~mol} / \mathrm{L}$ hydrochloric acid solution and constant volume. The supernatant was used for analysis of free amino acids: $0.15 \mathrm{~g}$ GLs with $10.0 \mathrm{ml} 6 \mathrm{~mol} / \mathrm{L}$ was hydrolyzed at $110{ }^{\circ} \mathrm{C}$ for 22 $\mathrm{h}$ in the sealed digestion tube. After filtering, $1.0 \mathrm{ml}$ of filtrate was dried under vacuum conditions and diluted appropriately for the analysis of total amino acids by the automated program. 


\section{Gas chromatographic-mass spectrometer (GC-MS) and scanning electron microscope (SEM) assay}

$2.0 \mathrm{~g}$ GLs were placed into a $15 \mathrm{ml}$ closed sample bottle; after $3 \mathrm{~h}$, the volatile matter in the bottle headspace was gathered using a 57310-U solid phase microextraction needle (Sigma-Aldrich, U.S.A.) for 30 min. The GC-MS analysis was conducted using a Thermo Fisher Trace ISQ-LT instrument (U.S.A.) with a DB-5MS column $(30 \mathrm{~m} \times 0.25 \mathrm{~mm} \times 0.25 \mu \mathrm{m})$. The carrier gas was helium (99.999\%), and with a constant flow of $1.0 \mathrm{~mL} / \mathrm{min}$. GC analysis conditions included an initial temperature of $40{ }^{\circ} \mathrm{C}$ for three min, first rising to $150{ }^{\circ} \mathrm{C}$ by $5{ }^{\circ} \mathrm{C} / \mathrm{min}$, then rising to $250{ }^{\circ} \mathrm{C}$ by $10{ }^{\circ} \mathrm{C} / \mathrm{min}$ and waiting for five min. MS conditions included electron ionization, an interface temperature of $250{ }^{\circ} \mathrm{C}$, electron impact at $70 \mathrm{eV}$, and a quality range of $35 \sim 450 \mathrm{~m} / \mathrm{z}$ for the full scan. The NIST library was used as the mass spectrum retrieval library.

For the SEM observations, first water was removed from the sample by a freezer drying program for $48 \mathrm{~h}$. The samples were then sputter-coated with gold and observed using the FEI Quanta200 SEM instrument (FEI, U.S.A.).

\section{Statistical analysis}

Variance analysis was carried out by the one-way ANOVA program of the SAS system for Windows 8.02 (SAS Institute Inc., U.S.A.). Duncan's multiple-range test was selected as the comparison method in the program, and the significance level was set at 0.05 or 0.01 . The correlation analyses were carried out by Origin 8.5 software (Origin Lab, U.S.A.) using either the linear fit or the polynomial fit program.

\section{Results and Discussion}

\section{Adaptability and growth of fungi in ginkgo leaf medium}

First and foremost, the selected fungal strain used for fermenting ginkgo leaves should have the strong growing ability in the GL medium. Twelve $A$. niger strains were evaluated: five from our lab and seven others separated from the ancient ginkgo tree soil in our previous work [32], including five A. niger and two A. niger var. awamori (Table 1). Eleven of the twelve strains except Gyx031 were able to survive in the ginkgo leaf medium with a $54.5 \%$ humidity ratio, without adding any other component. The medium was used mainly for screening strong adaptability of the strain and simultaneously for inducing production inputs and enhancing throughput of the FGL product. After five days, the fungal mycelia had covered the entire medium at $26{ }^{\circ} \mathrm{C}$; however, the microbes grew with different speeds in the culture. The translucent mycelia of Gyx017and Gyx086 covered the entire medium after $24 \mathrm{~h}$; Gyx003, Gyx105, Gyx091, Gyx027, Tu-A, and Tu-C took 36 h; the others required over $48 \mathrm{~h}$. The result indicated that ginkgo leaves supplied enough substances for the growth of all fungal strains except Gyx031, which could not survive in the medium, possibly because of sensitivity to anti-microbial medium components such as flavonoids [38] and ginkgolic acids [39]; a lack of other organisms in the medium whose coexistence facilitates survival in the soil[40]; or nutrient deficiency for that strain in the medium. In the published studies, the good growth of A. niger in GL medium usually required adding some additives, such as wheat bran [24], nutritive salt [24, 25, 41], maltose and peptone [27]. In this work, the medium is moisture GLs without any additive which could simplify production program and reduce cost, and the fast growth, especially Gyx017and Gyx086, is very benefit for increasing production efficiency.

\section{Quality of FGL and strain assessment}

To select the dominant strain, the 11 remaining A. niger strains were employed in fermenting GLs (Table 2). A series of quality indexes, including FPA, flavonoid content, protein, reducing sugar, and flavor were determined for each strain. Cellulase is an important additive to facilitate digestion of lignocellulose, decreasing the intestinal viscosity and increasing the nutritional value of feed [42]. The FPA reflects total cellulase activity, including endo- and exo-cellulase and $\beta$-glucosidase [43, 44]. The highest FPA value of $3.01 \pm 0.19 \mathrm{U} / \mathrm{g}$ dw FGL, which was significantly higher than the others $(\mathrm{p}<0.05)$, was obtained by the Gyx086 strain. Flavonoids are one of the important functional components in GLs, and comprise the major quality indexes of GLs [45]. Aspergillus spp. improves flavonoid extraction from GLs via solid-state fermentation more effectively than other species such as Penicillium spp. and Mucor spp. [32]. All GLs fermented by A. niger had a higher mean of flavonoid content than the control. Gyx017 resulted in the highest flavonoid content of $19.17 \pm 0.22 \mathrm{mg} / \mathrm{g}$ $\mathrm{dw}$, with the Gyx086 and Tu-A strains following. Reducing sugar is a beneficial component in the feed which can be directly absorbed in an animal's small intestine and contributes sweetness to improve GL taste. The reducing sugar content varies significantly in the GLs fermented by $A$. niger. The highest reducing sugar content, $66.2 \%$ higher than the control, was found in the culture fermented by Gyx086. This may explain the origin of this strain's significantly high FPA value, of note because ruminant animals first digest cellulose into 
monosaccharide via rumen microorganisms then absorb them in the small intestine, but mono-gastric animals cannot utilize lignocellulose [46]. Therefore the reducing sugar content is more important to monogastric animals than to ruminant animals. However, a few strains such as Gyx105 and Tu-B resulted in lower reducing sugar contents than the control. Protein is an important parameter to consider in the feed. Fungal growth increases the protein content; therefore, SSF has been used to improve the nutritional value of feed [28]. Unfermented GLs contain $14.26 \%$ crude protein, while FGLs have relatively higher crude protein content of $16.28 \%$. Fungus growth increases the protein content as the partial degradation of lignocellulose raises the proportion of protein [28, 42]. FGLs' sweet smell is far preferable to the control's highly unpleasant smell. Up to now no physical equipment method can replace humans in describing the feel feature of a sample, so the GL aroma and intensity were evaluated by a group of eight assessors using a sensory analysis of ranking method [35]. The aroma intensity was greatest in the samples fermented by Gyx091 and Tu-C, with a thick, sweet aroma. Lighter sweet aromas were given out from the GLs fermented by Gyx017, Gyx086, XA-10, and Tu-A. Other samples gave out a light, sweet aroma tainted by the unpleasant nature of the GL odor. The results discussed above were all used for strain assessment.

Traditional feed additives mainly supplement deficiencies in animal nutrition such as limited amino acids, mineral elements, and vitamins [28, 47]. GLs are a raw material for functional food or medical supplementation due to the biological activities of their natural components. FGLs contain not only these original ingredients but also microorganisms and enzymes, which are mainly functional, versus nutritional, feed additive. So the biological components, namely enzymes and flavonoids, were weighted more in evaluating the quality of FGL products. The weighted mean is widely used for dealing with such complex assessments involving multiple indicators and different contributions [35]. Thus the strain assessment score was calculated by the weighted arithmetic mean [36]; Gyx086 obtained the highest score of 79.5 and was thus selected for further experimentation as shown in Table 2.

\section{Temperature effect on growth, enzymes, flavonoids, and reducing sugar}

The temperature caused great fluctuation in fungus growth, enzyme activity, flavonoids, and sugar content during fermentation, as shown in Figure 1. Between 28 and $34{ }^{\circ} \mathrm{C}$, the respiratory intensity did not significantly differ $(p<0.05)$; however, it was significantly higher than the intensity at $25{ }^{\circ} \mathrm{C}$, which indicated that higher temperature promoted fungal growth in the beginning. The increased white fungal mycelia were also confirmed visually. A. niger had lower respiratory intensity after $48 \mathrm{~h}$ at $25-28{ }^{\circ} \mathrm{C}$, which revealed maturing and older mycelia. Black spores could be observed after $72 \mathrm{~h}$ at $34{ }^{\circ} \mathrm{C}$ and after $96 \mathrm{~h}$ at $31{ }^{\circ} \mathrm{C}$, but at $120 \mathrm{~h}$ for $25^{\circ} \mathrm{C}$ and $28{ }^{\circ} \mathrm{C}$. Interestingly, the second germinate of $A$. niger appeared after $96 \mathrm{~h}$ at a temperature of $34{ }^{\circ} \mathrm{C}$. The preferred temperature was $28-31{ }^{\circ} \mathrm{C}$ for FPA, demonstrating a higher and longer value under these temperature conditions. The content of flavonoids had a similar variation to FPA because of their positive relation and the release of flavonoids caused by cellulase decomposing cellulose in the cell wall [32, 48]. The flavonoids may have been used as a carbon source during fermentation as indicated by their gradual decrease in later stages of fermentation. During fermentation, a similar but more dramatic change was present in the content of reducing sugar in GLs. High FPA is beneficial to accumulate reducing sugar, but more is also consumed by the rapid growth of the fungus. The temperature from 28 to $31{ }^{\circ} \mathrm{C}$ is relatively favorable for fungal fermentation of GLs in terms of growth, enhancing FPA, and the content of flavonoids and reducing sugar.

Table 2. FPA, total flavonoids, reducing sugar, crude protein, smell and score by the weighted mean in the FGLs and the control.

\begin{tabular}{|c|c|c|c|c|c|c|c|}
\hline Code* & Species & $\begin{array}{l}\text { FPA }^{*} \\
(U / g \\
d w)\end{array}$ & $\begin{array}{l}\text { Total } \\
\text { flavonoids* } \\
(\mathrm{mg} / \mathrm{g} \mathrm{dw})\end{array}$ & $\begin{array}{l}\text { Reduci } \\
\text { ng } \\
\text { sugar* } \\
(\%)\end{array}$ & $\begin{array}{l}\text { Crude } \\
\text { Protein } \\
* \\
(\%)\end{array}$ & $\begin{array}{l}\text { Sweet } \\
\text { aroma } \\
\text { intensit } \\
y\end{array}$ & $\begin{array}{l}\text { Scor } \\
\text { e }\end{array}$ \\
\hline Control & & 0 & $15.81 \pm 0.12^{\mathrm{e}}$ & $\begin{array}{l}1.51 \pm \\
0.13 \mathrm{e}\end{array}$ & $\begin{array}{l}14.26 \pm \\
0.11 \mathrm{e}\end{array}$ & - & 10.0 \\
\hline Gyx003 & A. niger & $\begin{array}{l}2.07 \pm \\
0.33^{b}\end{array}$ & $\begin{array}{l}16.31 \pm 0.79 \\
d\end{array}$ & $\begin{array}{l}2.04 \pm \\
0.03 c\end{array}$ & $\begin{array}{l}17.58 \pm \\
0.26 \text { a }\end{array}$ & + & 55.5 \\
\hline Gyx017 & A. awamori & $\begin{array}{l}1.35 \pm \\
0.40 \mathrm{e}\end{array}$ & $19.17 \pm 0.22 \mathrm{a}$ & $\begin{array}{l}2.21 \pm \\
0.07 \mathrm{~b}\end{array}$ & $\begin{array}{l}15.09 \pm \\
0.30 c\end{array}$ & ++ & 69.5 \\
\hline Gyx027 & A. niger & $\begin{array}{l}1.11 \pm \\
0.21 \mathrm{e}\end{array}$ & $17.24 \pm 0.65 c$ & $\begin{array}{l}2.07 \pm \\
0.66 c\end{array}$ & $\begin{array}{l}14.98 \pm \\
0.39 c\end{array}$ & + & 46.0 \\
\hline Gyx086 & A. niger & $\begin{array}{l}3.01 \pm \\
0.19 a\end{array}$ & $18.49 \pm 0.45 b$ & $\begin{array}{l}2.51 \pm \\
0.36 \text { a }\end{array}$ & $\begin{array}{l}15.21 \pm \\
0.20^{c}\end{array}$ & ++ & 79.5 \\
\hline Gyx091 & A. niger & $\begin{array}{l}1.79 \pm \\
0.24^{c}\end{array}$ & $\begin{array}{l}16.25 \pm 0.31 \\
d\end{array}$ & $\begin{array}{l}2.21 \pm \\
0.48 b\end{array}$ & $\begin{array}{l}15.27 \pm \\
0.30 c\end{array}$ & +++ & 59.0 \\
\hline Gyx105 & A. awamori & $\begin{array}{l}1.74 \pm \\
0.35 c\end{array}$ & $\begin{array}{l}16.10 \pm 0.35 \\
d\end{array}$ & $\begin{array}{l}1.18 \pm \\
0.31^{\mathrm{f}}\end{array}$ & $\begin{array}{l}15.27 \pm \\
0.13 c\end{array}$ & + & 37.0 \\
\hline XA-8 & A. niger & $\begin{array}{l}1.02 \pm \\
0.26^{f}\end{array}$ & $18.39 \pm 0.37 b$ & $\begin{array}{l}1.91 \pm \\
0.20 \mathrm{~d}\end{array}$ & $\begin{array}{l}15.26 \pm \\
0.26 c\end{array}$ & + & 42.0 \\
\hline XA-10 & A. niger & $\begin{array}{l}1.09 \\
\pm 0.17 \mathrm{f}\end{array}$ & $16.01 \pm 0.19 \mathrm{~d}$ & $\begin{array}{l}2.01 \pm \\
0.24^{c}\end{array}$ & $\begin{array}{l}15.25 \pm \\
0.51 c\end{array}$ & ++ & 37.0 \\
\hline Tu-A & A. niger & $\begin{array}{l}1.41 \\
\pm 0.16 \mathrm{e}\end{array}$ & $18.42 \pm 0.57^{b}$ & $\begin{array}{l}1.72 \pm \\
0.15^{\mathrm{d}}\end{array}$ & $\begin{array}{l}15.73 \pm \\
0.37 \mathrm{~b}\end{array}$ & ++ & 61.0 \\
\hline Tu-B & A. niger & $\begin{array}{l}1.03 \\
\pm 0.28^{f}\end{array}$ & $18.16 \pm 0.61^{b}$ & $\begin{array}{l}1.29 \pm \\
0.14^{f}\end{array}$ & $\begin{array}{l}14.34 \pm \\
0.16^{\mathrm{d}}\end{array}$ & + & 34.0 \\
\hline Tu-C & A. niger & $\begin{array}{l}1.68 \\
\pm 0.39 \text { c }\end{array}$ & $18.31 \pm 0.48 b$ & $\begin{array}{l}1.91 \pm \\
0.27 \mathrm{~d}\end{array}$ & $\begin{array}{l}15.08 \pm \\
0.22 c\end{array}$ & +++ & 66.0 \\
\hline
\end{tabular}

Notes: The control is an unfermented ginkgo leaves samples; the different superscript letters in each column represent significant differences of mean values by Duncan's multiple-range test with $\alpha=0.05$. 


\section{Effect of GL humidity ratio on growth, enzymes, flavonoids, and reducing sugar}

The growth of the fungus was greatly affected by the humidity ratio of the GL medium, which ranged from $40 \%$ to $70 \%$ as shown in Figure 2. Sequentially the FPA and the content of flavonoids and reducing sugar were also affected. The respiration intensity at $40 \%$ and $50 \%$ water ratios in the medium was significantly higher than at $60 \%$ or $70 \%(p<0.05)$. In particular, the white hyphae covered on the former were obviously greater than the latter, perhaps due to a higher air capacity. Beyond a $50 \%$ water ratio, the highest fungal rate of respiration intensity was found in the culture with a $60 \%$ humidity ratio. A greater humidity ratio, e.g. $70 \%$, reduced the oxygen in the culture, which delayed fungal growth. The FPA and flavonoid content in the medium appear to be increasing early on and later appear to decline during the fermenting period; higher values were present in the medium with $50 \%-60 \%$ of humidity content, proving better for fungal growth, improving FPA, and releasing flavonoids.
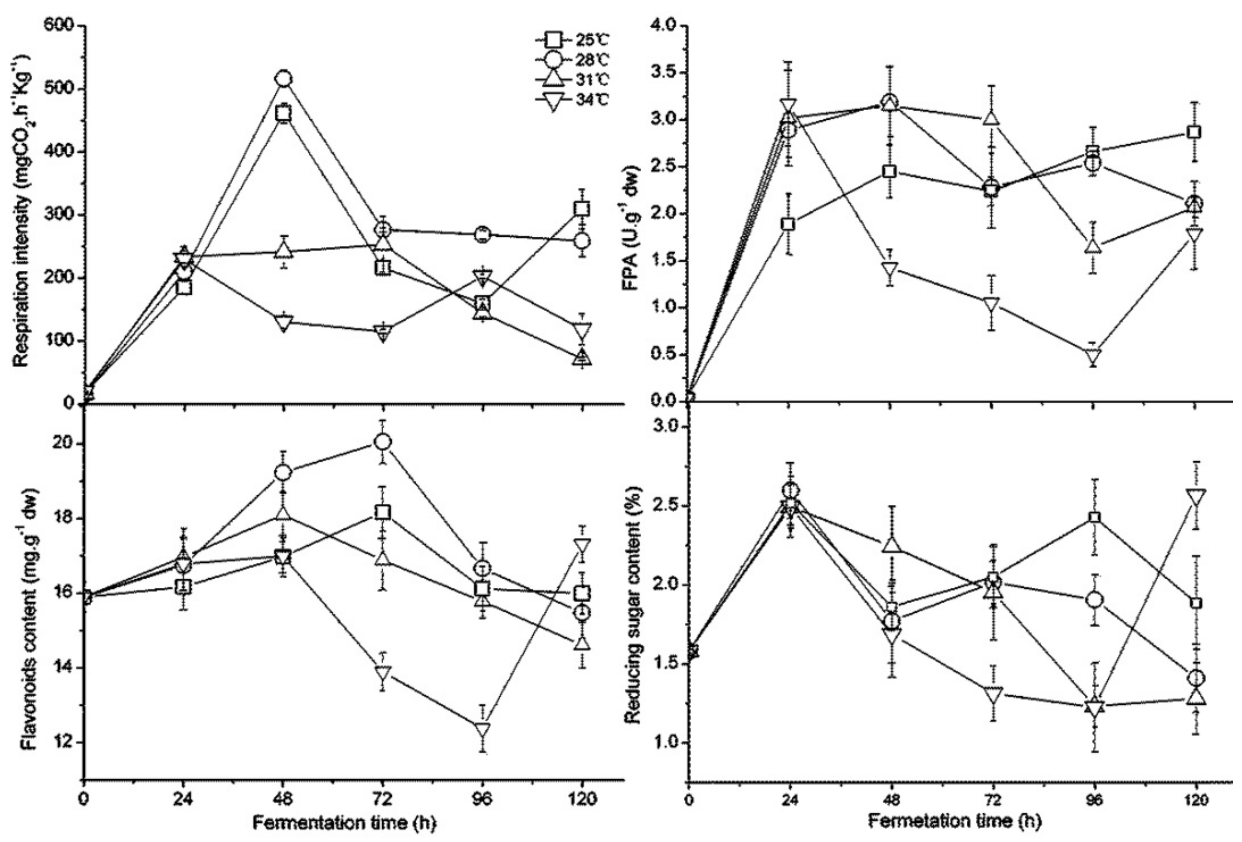

Figure 1. Changes in the fungal growth, FPA, flavonoids, and reducing sugar content during fermentation by Gyx086 at temperatures from $25{ }^{\circ} \mathrm{C}$ to $34{ }^{\circ} \mathrm{C}$ with humidity $54 \%$ by inoculating three loops of agar culture.
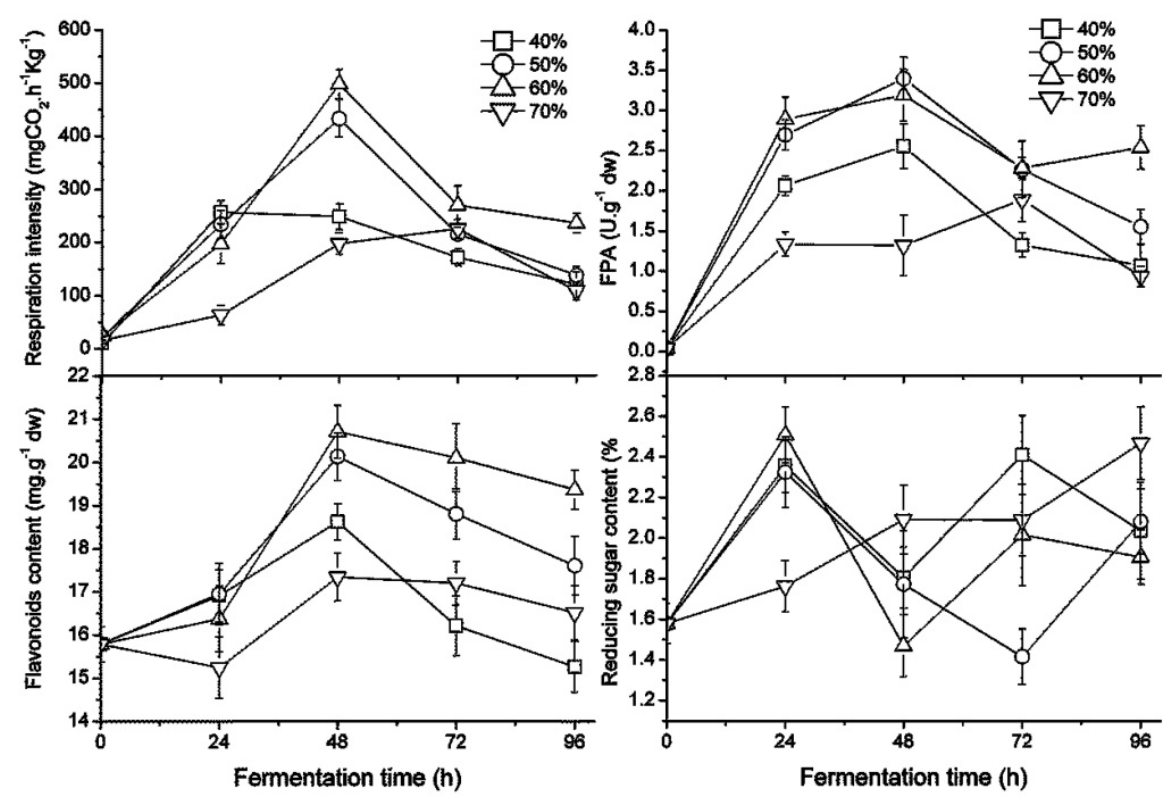

Figure 2. Changes in fungal growth, FPA, flavonoids and reducing sugar content during fermentation with different humidity ratio in GLs cultures at $28{ }^{\circ} \mathrm{C}$ by inoculating three loops of plate culture. 

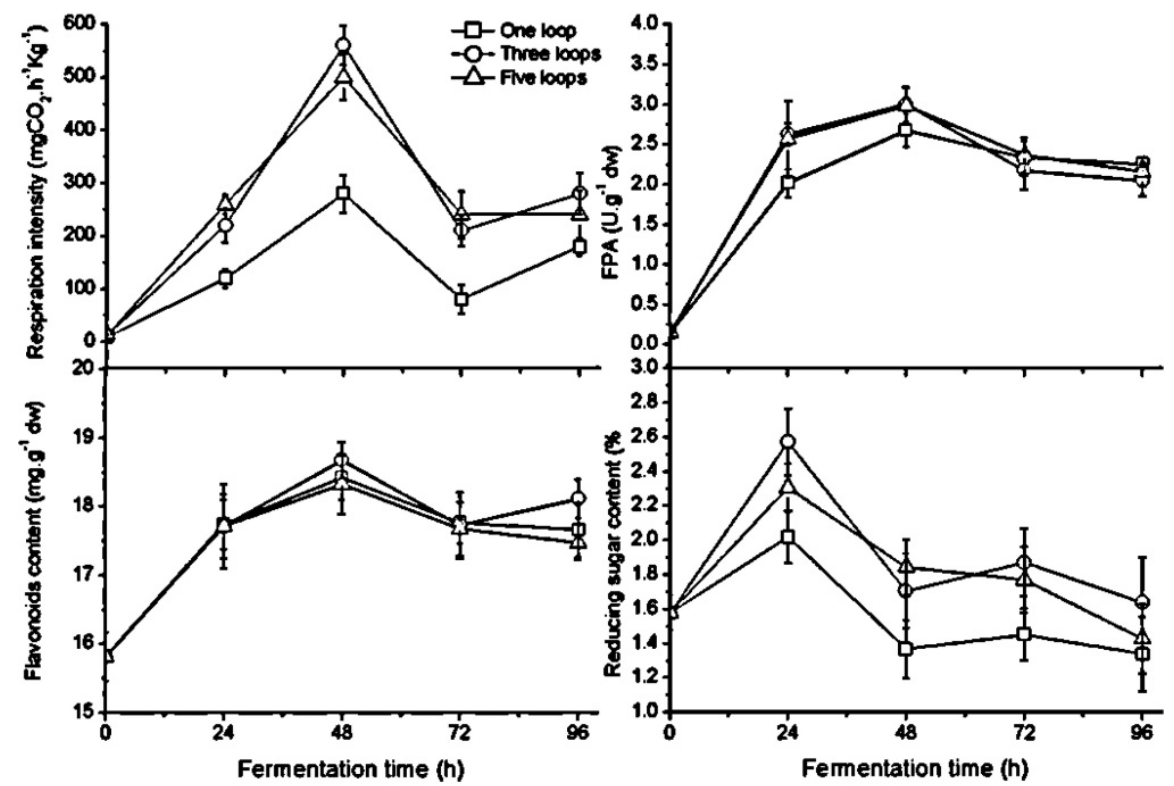

Figure 3. Changes in fungal growth, FPA, flavonoids and reducing sugar content during fermentation with different inoculum size in GLs cultures with humidity ratio of $60 \%$ at $28{ }^{\circ} \mathrm{C}$

Pairwise correlation analyses were carried out by the linear fit or the polynomial fit program of Origin 8.5. There was not always a correlation between two factors. A linear positive correlation only appeared between growth and FPA in the culture of $40 \%$ or 50 $\%$, with an adj. R-square of 0.928 for the former ( $p<$ $0.01)$ and 0.862 for the later $(\mathrm{p}<0.05)$. A polynomial correlation presented between FPA and flavonoid content in the $40 \%$ culture, with an adj. R-square of $0.907(p<0.05)$. Reducing sugar content had no linear correlation with other factors. It was difficult to establish a model among these factors, likely because SSF is a complicated, heterogeneous system that includes multiple phases of mass transfer among gas-liquid, gas-solid, and liquid-solid [49]. Therefore there is great non-uniformity in many aspects, such as fungi distribution, median temperature and humidity, and secreted metabolic products and substrate content with degradation, which prevents confirmation of the relevancy among factors.

\section{Effect of inoculum size on growth, enzymes, flavonoids, and reducing sugar}

Unlike the temperature and the humidity ratio, the inoculum size doesn't affect fermentation progress. Fungal growth, FPA, flavonoids, and reducing sugar demonstrated a similar change pattern with different inoculum sizes during fermentation (Figure 3). A significantly higher respiration rate appeared in the culture inoculating three and five loops of $A$. niger compared to a single loop ( $p<0.05)$. The respiratory crest of the polygonal line appears at $48 \mathrm{~h}$ in all three cultures and subsequently declines, indicating the aging mycelium with black sporangia observed in the medium at $72 \mathrm{~h}$. The FPA and sugar content have uniform peak times compared to the growth peak but have small differences among the three different inoculum sizes. FPA is not significantly different in the culture of one loop versus the other two in the later stage of fermentation; the values of flavonoid content were no different during the period of $72 \mathrm{~h}$ fermentation. Three and five loops of inoculum size gave rise to relatively higher sugar content than one loop did; there was no significant difference between the two during fermentation. Thus according to respiration rate, the results suggested that one loop of inoculum size was too little and three loops were sufficient for each bottle with 65 grams of GL medium.

\section{Aroma of GL fermented by Gyx086}

Voluntary intake studies have been used to form indices of forage quality and have found that adding flavor into feed leads to an increase in animal weight gain $[50,51]$. However, unfermented GLs have a very unpleasant odor, denoted ginkgo leaf odor (GLO). With active enzyme systems, fermentation usually changes the flavor of food or feed [52]. All fermented ginkgo leaves gave off a pleasantly fragrant and sweet odor during mycelium growth according to nose sniffing, but delayed fermentation was disadvantageous to the improved aroma, which was subsequently slowly reduced and even lost when fungal spores formed. This flavor features unfermented and fermented GLs could be determined by the e-nose and clearly distinguished by the PCA 
from days 0 to 5 (Figure 4A). Three regions can be determined: the left region including the $2^{\text {nd }}$ and $3^{\text {rd }}$ days shows an excellent, sweet aroma; the middle region including the $1^{\text {st }}, 4^{\text {th }}$ and $5^{\text {th }}$ days shows a light, sweet aroma accompanied by the slight unpleasant odor of GLs; and the unfermented GLs have GLO but no sweet aroma. Furthermore, a few fungi belonging to Penicillium spp. and Mucor spp. were also used to ferment ginkgo leaves and presented a consistent PCA result, supporting the use of PCA for assessing the aroma character and quality of FGLs.
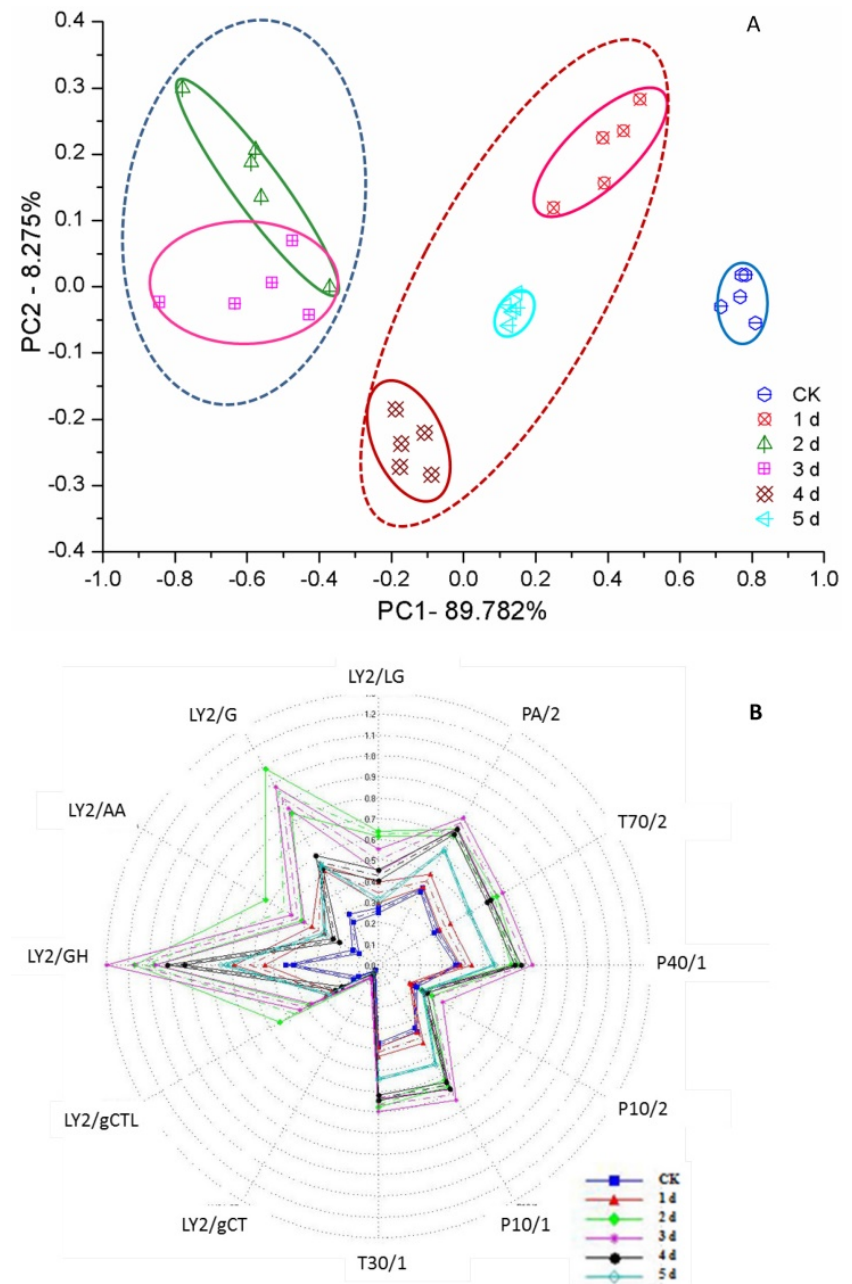

Figure 4. PCA (A) and radar (B) map of smell analysis of unfermented and fermented ginkgo leaves by the electrical nose

To investigate volatile matter compounds, various sensors' electric signal strengths were plotted as a radar map. As shown in Figure 4B, all FGLs demonstrated relatively higher response values on the sensors than the unfermented GLs. The sensor for LY2/G and LY2/GH compounds, which is also very sensitive to small molecules of ammonia, amines, and carbon oxide, showed a particularly strong signal for the $2^{\text {nd }}$ and $3^{\text {rd }}$-day samples, suggesting that the sweet aroma likely originates from these compounds.
GC-MS analysis usually helps to identify volatile compounds [53-55], and the chromatogram of GC-MS showed component variations after fermenting GLs (Figure 5). However, according to GC-MS analysis, there were fewer than five compounds from each sample that could be identified using the NIST standard reference.

\section{Appropriate conditions for fermenting GLs using Gyx086}

The quality of FGLs was determined according to a multi-index, including sensory index, functional components, enzymes, and nutritive index. These, in turn, were determined by fermenting conditions including temperature, water ratio, inoculum size, and fermentation time in natural $\mathrm{pH}$ conditions. However, the mathematical system of multiple independent and dependent variables is very complex, and there was a time difference between high FPA and high flavonoid content results; thus, it was very difficult to find a model for optimizing fermentation conditions. This study split the difference among FGL quality indices according to the above progressive single factor experiments. From the temperature experiment, $28{ }^{\circ} \mathrm{C}$ was selected as the optimal fermentation temperature based the higher level of FPA and flavonoids. At this temperature, the humidity ratio of $60 \%$ is beneficial for higher growth, FPA, and flavonoids. When fermenting at $28{ }^{\circ} \mathrm{C}$ with $60 \%$ water to GL ratio, the inoculum size experiment indicated that three loops of spores for every $30 \mathrm{~g}$ of GLs $(\mathrm{dw})$ is appropriate. Fermentation time is most difficult to confirm because the best fermentation times are different for FPA $(<48 \mathrm{~h})$ and flavonoids (> $48 \mathrm{~h}$ ), as shown when comparing Figures $1-3$. This time asynchronization derives from the causality between enzymes and flavonoids. The cellulosic degradation by cellulase enzymes accelerates flavonoid release from GL cells [56]; thus, a higher FPA is usually followed by relatively high flavonoid content in this study. In our previous study, the optimized time for flavonoid extraction from GLs was $61 \mathrm{~h}$ with a water ratio of $64.2 \%$ in the culture and fermentation at $27.8{ }^{\circ} \mathrm{C}$ [32]. Notably, this time is different from that of high FPA. FPA and flavonoids were equally weighted in terms of biological functionality of the GL feed additive. A balanced time for fermentation was thus selected as $48 \mathrm{~h}$. The optimal fermentation conditions for temperature, humidity ratio, inoculum size, and fermentation time are $28 \pm 0.5^{\circ} \mathrm{C}, 60 \pm 1 \%, 3$ loops for $30 \mathrm{~g}(\mathrm{dw})$ medium, and $48 \mathrm{~h}$, respectively. Under these conditions, the quality indices of FGLs were further investigated. 


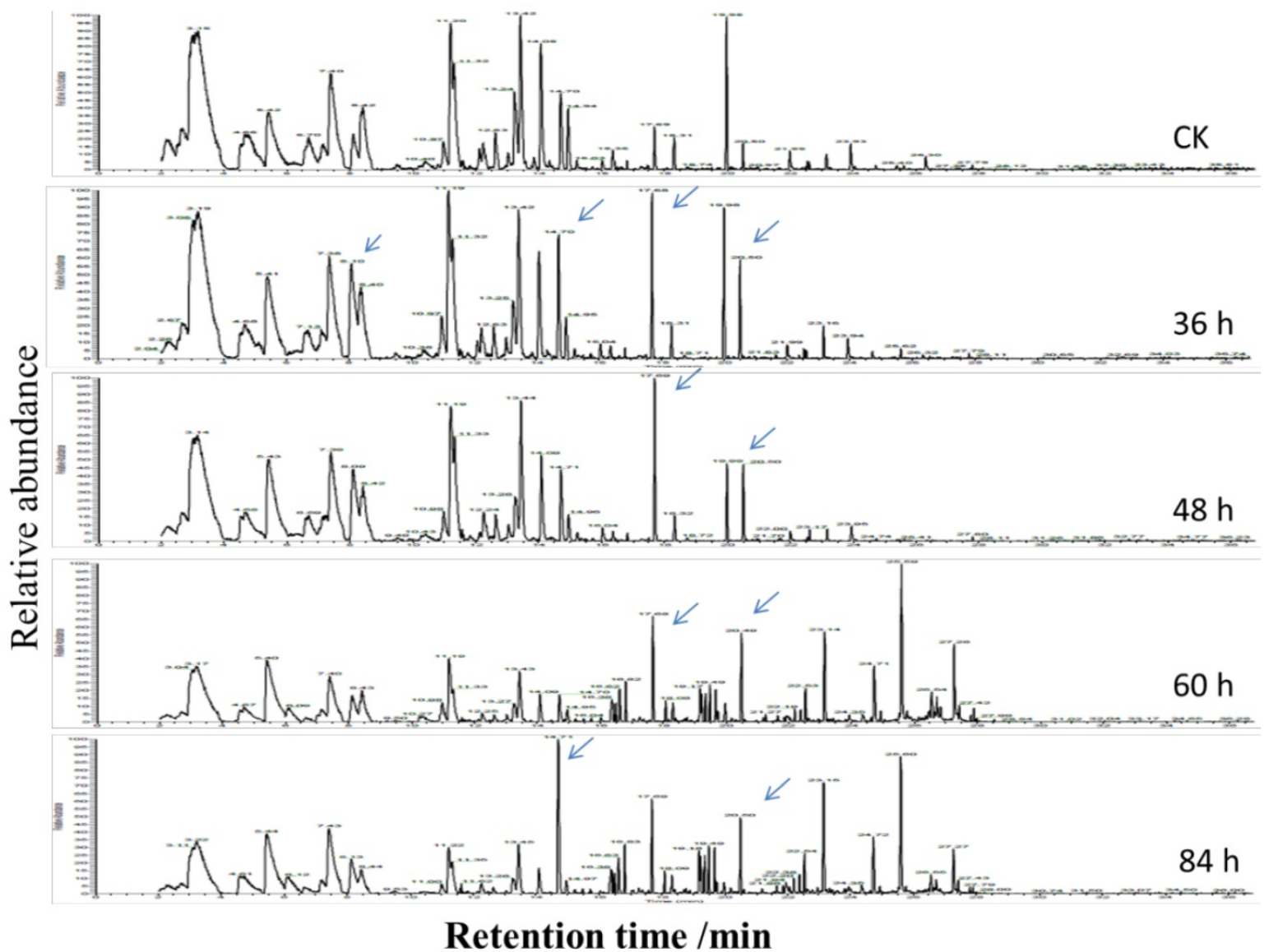

Figure 5. The chromatogram of GC-MS of the volatile compounds of unfermented and fermented ginkgo leaves. The significant changes of component peaks are directed by the arrows.

\section{Small-scale production test of fermented GLs by $\mathrm{Gyx} 086$}

Based on the fermentation conditions established above, a small-scale production test of $15 \mathrm{~kg}$ of GLs was carried out; $12.25 \mathrm{~kg}$ of FGLs were harvested, and the physical, chemical and biological qualities were investigated (Figure 6 and Table 3). Figure 6 shows that the biomass of GL tissue was partly degraded and consumed after fermentation, which is likely responsible for the lost weight. The FGL product was smaller and more malleable than unfermented GLs, which is advantageous for the additives to be scattered into feed materials. The extracellular cellulase activity of exo- and endo- cellulase and $\beta$-glucosidase was $0.13 \pm 0.01,5.11 \pm 0.29$, and $8.36 \pm$ $0.33 \mathrm{U} / \mathrm{g} \mathrm{dw}$, respectively (Table 3 ). The total cellulase activity, FPA, was $3.19 \pm 0.37 \mathrm{U} / \mathrm{g} \mathrm{dw}$; the cellulase had excellent acid resistance in a lower $\mathrm{pH}$ of 2.0 in our other study of enzyme characteristics (data not yet published). The feed additive of cellulase can eliminate anti-nutritional factors, supply animals' own digestive enzymes and improve the feed utilization for mono-gastric or ruminant animals [42]. This is the likely reason that the feed/gain ratio of broiler chicks is significantly higher by intake FGLs than un-FGLs [24, 25].The total flavonoid content is $19.95 \pm 0.23 \mathrm{mg}$ per gram dry FGLs, which is $26 \%$ higher than unfermented GLs, and also greatly higher than the previous studies [24, 26]. Broken cell walls (Figure 6) can improve flavonoid extraction by an enzyme or microbial pretreatment $[32,56]$.The main aglycone flavonoids in GLs are quercetin, kaempferol, and isorhamnetin, but the content of these three aglycones was less than $0.1 \%$, indicating that flavonoids mainly exist as glycosides [32], which are more advantageous for absorption in the intestinal tract [56]. Flavonoids are likely the main factor helping improve animal's intestinal and immune function [24, 27]. Reducing sugar and organic acids $(\mathrm{pH} 3.54)$ can supply sweet and sour flavors to improve FGL taste and enhance feed intake [28, 35, 50]. Fermentation is very beneficial for improving GL aroma; the unpleasant odor of unfermented GLs was eliminated during fermentation, and FGLs demonstrated a pleasant, thick, sweet-smelling odor. This is an expressly desired change brought about by the fermenting process for feed and food [52]. The CFU amount of $A$. niger was $2.83 \times 10^{9}$ per gram dried FGL. $A$. niger, including its secreted enzyme, has already 
been accepted since 1972 by FAO/WHO experts, and the FDA has considered A. niger to be "generally regarded as safe" (GRAS) [57]. This fungus is currently listed under direct-fed microbes (DFMS) by China and U.S.A. Furthermore, the GLs fermented by $A$. niger and used for feed additive has been certified as safe in our previous studies [24-26, 41]. However, further research is needed to determine if the benefit of the feed additive is mainly contributed by A. niger or flavonoids. The crude protein content is also significantly higher in FGLs than in unfermented GLs, at $14.5 \%$ above the control, but the balance of amino acids is more important for animal nutrition [47].
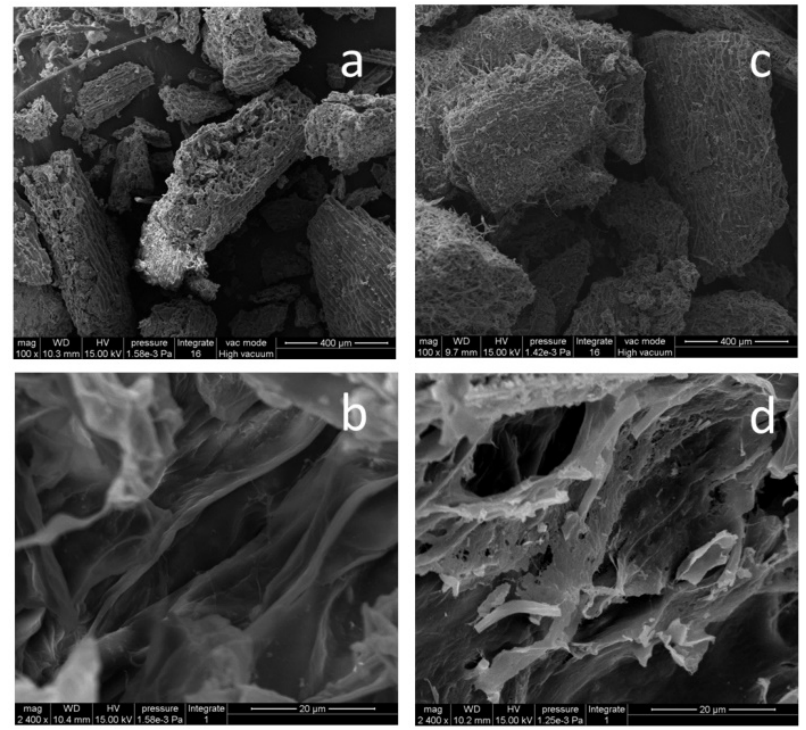

Figure 6. SEM of unfermented GLs and FGLs (a) unfermented GLs 100×, (b) unfermented GLs 2400×, (c) FGLs 100×, (d) FGLs 2400×.

\section{Amino acids of GLs fermented by Gyx086}

Animal feed requires certain crude protein levels to meet animal production performance, particularly for non-ruminants due to their unavailability of inorganic-N [28, 47]. Moreover, the efficiency of utilization of protein depends on digestible essential amino acids [47]; thus the content and composition of amino acids is an important factor for animal feed. The amount of free and total amino acids in the GLs fermented by Gyx086 were 14.77 and $95.07 \mathrm{mg}$ per gram, respectively, (Table 4) which was $96.41 \%$ and $16.49 \%$ higher than the control, respectively. These results indicated that fermentation processing enhanced GL amino acid content, particularly free amino acids that are more beneficial for animal absorption. The total aromatic amino acids, isoleucine and valine, were plentiful with content more than 62.6 $\mathrm{mg}$ ( only Phe. and Tyr. ), $31 \mathrm{mg}$, and $39 \mathrm{mg}$ per gram crude protein, respectively, compared to minimum requirements of $63 \mathrm{mg}, 28 \mathrm{mg}$, and $35 \mathrm{mg}$ per gram crude protein, respectively [58]. On the other hand, leucine, lysine, threonine, and total sulfur amino acid results are less than the required $66 \mathrm{mg}, 58 \mathrm{mg}$, $63 \mathrm{mg}$, and $25 \mathrm{mg}$ per gram crude protein in GLs, with the FGLs demonstrating a smaller gap than the control (Table 4).

Table 3. Cellulase activities, flavonoids, flavonoid aglycone, crude protein and $A$. niger in the FGLs fermented by $\mathrm{Gyx} 086$ with water ratio $60 \%$ at $28 \pm 0.5^{\circ} \mathrm{C}$ for $48 \mathrm{~h}$.

\begin{tabular}{|c|c|c|c|c|c|}
\hline & Control & FGLs & & Control & FGLs \\
\hline $\begin{array}{l}\text { FPA } \\
\text { (U/g dw) }\end{array}$ & 0 & $\begin{array}{l}3.19 \pm \\
0.37\end{array}$ & $\begin{array}{l}\text { Isorhamnetin } \\
(\mu \mathrm{g} / \mathrm{g} d w)\end{array}$ & $1.82 \pm 0.25$ & $2.57 \pm 0.41^{*}$ \\
\hline $\begin{array}{l}\text { Exo-cellulase } \\
\text { (U/g dw) }\end{array}$ & 0 & $\begin{array}{l}0.13 \pm \\
0.01\end{array}$ & $\begin{array}{l}\text { Reducing } \\
\text { sugar }(\mathrm{mg} / \mathrm{g})\end{array}$ & $\begin{array}{l}14.92 \pm \\
1.32\end{array}$ & $24.28 \pm 2.35^{\star}$ \\
\hline $\begin{array}{l}\text { Endo-cellulase } \\
\text { (U/g dw) }\end{array}$ & 0 & $\begin{array}{l}5.11 \pm \\
0.29\end{array}$ & $\mathrm{pH}$ & $5.68 \pm 0.03$ & $3.54 \pm 0.09^{*}$ \\
\hline $\begin{array}{l}\beta \text {-glucosidase } \\
(\mathrm{U} / \mathrm{g} \mathrm{dw})\end{array}$ & 0 & $\begin{array}{l}8.36 \pm \\
0.33\end{array}$ & Odor & $\begin{array}{l}\text { Thick } \\
\text { distasteful } \\
\text { GLs smell }\end{array}$ & $\begin{array}{l}\text { Thick } \\
\text { pleasant } \\
\text { sweet smell }\end{array}$ \\
\hline $\begin{array}{l}\text { Total } \\
\text { flavonoids } \\
(\mathrm{mg} / \mathrm{g} \mathrm{dw})\end{array}$ & $\begin{array}{l}15.83 \pm \\
0.15\end{array}$ & $\begin{array}{l}19.95 \pm \\
0.23^{*}\end{array}$ & $\begin{array}{l}\text { A. niger } \\
\left({ }^{*} 10^{9} \mathrm{CFU} / \mathrm{g}\right. \\
\text { dw) }\end{array}$ & 0 & $2.83 \pm 0.17$ \\
\hline $\begin{array}{l}\text { Quercetin } \\
(\mu \mathrm{g} / \mathrm{g} d w)\end{array}$ & $\begin{array}{l}37.25 \pm \\
1.65\end{array}$ & $\begin{array}{l}49.73 \pm \\
1.84^{*}\end{array}$ & $\begin{array}{l}\text { Crude protein } \\
(\mathrm{mg} / \mathrm{g} \mathrm{dw})\end{array}$ & $\begin{array}{l}142.09 \pm \\
2.94\end{array}$ & $\begin{array}{l}162.81 \pm \\
3.46^{*}\end{array}$ \\
\hline $\begin{array}{l}\text { Kaempferol } \\
(\mu \mathrm{g} / \mathrm{g} d w)\end{array}$ & $\begin{array}{l}7.16 \pm \\
0.93\end{array}$ & $\begin{array}{l}10.96 \pm \\
0.22^{*}\end{array}$ & $\begin{array}{l}\text { Mass weight } \\
\text { (kg) }\end{array}$ & 15.00 & 12.25 \\
\hline
\end{tabular}

* Significant difference by variance analysis with $\alpha=0.05$

Table 4. The contents of free amino acids and total amino acid in FGLs and un-FDLs

\begin{tabular}{|c|c|c|c|c|c|c|}
\hline \multirow[b]{3}{*}{ Name } & \multirow{2}{*}{\multicolumn{2}{|c|}{ Free amino acid /mg.g-1 }} & \multicolumn{4}{|c|}{ Total amino acid } \\
\hline & & & \multicolumn{2}{|c|}{ Unfermented } & \multicolumn{2}{|c|}{ Fermented GLs } \\
\hline & $\begin{array}{l}\text { Un- } \\
\text { fermented } \\
\text { GLs }\end{array}$ & $\begin{array}{l}\text { Fermented } \\
\text { GLs }\end{array}$ & $\begin{array}{l}\text { mg.g-1 } \\
\text { GLs }\end{array}$ & $\begin{array}{l}\mathrm{mg} / \mathrm{g} \\
\text { crude } \\
\text { protein }\end{array}$ & mg.g-1 GLs & $\begin{array}{l}\mathrm{mg} / \mathrm{g} \\
\text { crude } \\
\text { protein }\end{array}$ \\
\hline Asp & $1.97 \pm 0.28$ & $1.50 \pm 0.13$ & $9.71 \pm 0.19$ & 68.09 & $\begin{array}{l}11.09 \pm \\
0.30^{*}\end{array}$ & 73.14 \\
\hline Thr & $0.46 \pm 0.08$ & $1.75 \pm 0.10^{* *}$ & $3.92 \pm 0.24$ & 27.49 & $4.50 \pm 0.11^{*}$ & $\begin{array}{l}29.68 \\
(34)\end{array}$ \\
\hline Ser & $1.38 \pm 0.11$ & $0.61 \pm 0.07$ & $4.50 \pm 0.15$ & 31.56 & $5.09 \pm 0.14^{*}$ & 33.57 \\
\hline Glu & $1.51 \pm 0.14$ & $2.77 \pm 0.18^{* *}$ & $9.45 \pm 0.31$ & 66.27 & $10.69 \pm 0.37^{*}$ & 70.51 \\
\hline Gly & $0.24 \pm 0.05$ & $0.38 \pm 0.02^{* *}$ & $6.14 \pm 0.08$ & 43.06 & $7.15 \pm 0.19^{*}$ & 47.16 \\
\hline Ala & $0.05 \pm 0.01$ & $0.61 \pm 0.11^{* *}$ & $5.22 \pm 0.16$ & 36.61 & $6.07 \pm 0.25^{*}$ & 40.03 \\
\hline Cys & $0.01 \pm 0.00$ & $0.23 \pm 0.05^{\star *}$ & $1.24 \pm 0.17$ & 8.70 & $1.53 \pm 0.21$ & 10.09 \\
\hline Val & $0.03 \pm 0.01$ & $0.44 \pm 0.05^{* *}$ & $5.27 \pm 0.23$ & 36.96 & $6.05 \pm 0.20^{*}$ & $\begin{array}{l}39.90 \\
(35)\end{array}$ \\
\hline Met & 0 & $0.05 \pm 0.01^{* *}$ & $0.58 \pm 0.04$ & 4.07 & $0.64 \pm 0.03$ & 4.22 \\
\hline Ile & $0.01 \pm 0.00$ & $0.20 \pm 0.01^{* *}$ & $4.08 \pm 0.19$ & 28.61 & $4.75 \pm 0.17^{*}$ & $\begin{array}{l}31.33 \\
(28)\end{array}$ \\
\hline Leu & $0.01 \pm 0.01$ & $0.31 \pm 0.04^{* *}$ & $7.01 \pm 0.27$ & 49.16 & $8.13 \pm 0.35^{*}$ & $\begin{array}{l}53.62 \\
(66)\end{array}$ \\
\hline Tyr & $0.02 \pm 0.00$ & $1.02 \pm 0.13^{* *}$ & $3.25 \pm 0.03$ & 22.79 & $3.85 \pm 0.11^{*}$ & 25.39 \\
\hline Phe & $0.01 \pm 0.01$ & $0.65 \pm 0.11^{* *}$ & $4.85 \pm 0.15$ & 34.01 & $5.65 \pm 0.17^{*}$ & 37.26 \\
\hline His & $0.07 \pm 0.01$ & $1.47 \pm 0.22^{* *}$ & $2.68 \pm 0.13$ & 18.79 & $3.54 \pm 0.26^{*}$ & 23.35 \\
\hline Lys & $0.02 \pm 0.00$ & $1.07 \pm 0.14^{* *}$ & $4.66 \pm 0.14$ & 32.68 & $5.55 \pm 0.23^{*}$ & $\begin{array}{l}36.60 \\
(58)\end{array}$ \\
\hline Arg & $0.02 \pm 0.01$ & $0.87 \pm 0.08^{* *}$ & $4.33 \pm 0.25$ & 30.36 & $5.19 \pm 0.19^{*}$ & 34.23 \\
\hline Pro & $1.73 \pm 0.09$ & $0.88 \pm 0.10$ & $4.72 \pm 0.17$ & 33.10 & $5.60 \pm 0.34^{*}$ & 36.93 \\
\hline Total & $7.52 \pm 0.04$ & $\begin{array}{l}14.77 \pm \\
0.35^{* *}\end{array}$ & $\begin{array}{l}81.61 \pm \\
0.62\end{array}$ & 572.33 & $95.07 \pm 0.81^{*}$ & 627.03 \\
\hline
\end{tabular}

Note: ${ }^{*} \alpha=0.05,{ }^{* *} \alpha=0.01$, significantly higher than unfermented GLs; The bold type mark for essential amino acid; \# FAO/WHO/UNU amino acid requirement pattern based on amino acid requirements of preschool-age child [58], moreover, the total sulfur amino acids and total aromatic amino acids are 25 and 63 . 
Animals not only have dietary requirements for essential amino acids but also need nutritionally nonessential amino acids to achieve maximum growth and production performance [59]. Therefore increasing nonessential amino acids is very important and beneficial for animals. In addition to the myriad other benefits, almost all of the total nonessential amino acid content was also improved through GL fermentation by the Gyx086 strain.

\section{Abbreviations}

GL/s: Ginkgo leaf/leaves, FGLs: Fermented ginkgo leaves, EGb: Ginkgo biloba extract, SSF: Solid-state fermentation, dw: dry weight, PCA: Cluster analysis program, GC-MS: Gas chromategraphic-mass spectrometer, SEM: Scanning electron microscope, GLO: Ginkgo leaf odor.

\section{Acknowledgements}

We thank the scholars in biology department at Lakehead University improving our writing.

\section{Funds}

National key research and development projects "Key technological study of efficiently cultivating ginkgo tree for using the leaf and testa and their integrated utilization"; Jiangsu postdoctoral fund "Mechanism of efficient accumulation flavonoids in Ginkgo biloba leaves fermented by Aspergillus niger" ; Priority Academic Program Development of Jiangsu Higher Education Institution(PAPD); The talent fund from Nanjing forestry university fund "Analysis of enzymatic system secreted during fermenting ginkgo leaves by Aspergillus niger Gyx086 and construction of enzymatic system for degradation of ginkgo leaf" .

\section{Competing Interests}

The authors have declared that no competing interest exists.

\section{References}

1. Diamond BJ, Mondragon A. Ginkgo biloba. Complementary and Integrative Treatments in Psychiatric Practice. Washington: American Psychiatric Association Publishing. 2017; 149p.

2. Van Beek TA. Chemical analysis of Ginkgo biloba leaves and extracts. J Chromatogr A. 2002; 967: 21-55.

3. Singh B, Kaur P, Singh R, Ahuja P. Biology and chemistry of Ginkgo biloba. Fitoterapia. 2008; 79: 401-18.

4. Maitra I, Marcocci L, Droy-Lefaix MT, Packer L. Peroxyl radical scavenging activity of Ginkgo biloba extract EGb 761. Biochem Pharmacol. 1995; 49: 1649-55.

5. Bridi R, Crossetti F, Steffen V, Henriques A. The antioxidant activity of standardized extract of Ginkgo biloba (EGb 761) in rats. Phytother Res. 2001; 15: 449-51.

6. Bustanji Y, Al-Masri IM, Mohammad M, Hudaib M, Tawaha K, Tarazi H, et al. Pancreatic lipase inhibition activity of trilactone terpenes of Ginkgo biloba. J Enzyme Inhib Med Chem. 2011; 26: 453-9.

7. Kang JW, Kim JH, Song K, Kim SH, Yoon JH, Kim KS. Kaempferol and quercetin, components of Ginkgo biloba extract (EGb 761), induce caspase-3-dependent apoptosis in oral cavity cancer cells. Phytother Res. 2010; 24.
8. DeFeudis FV, Papadopoulos V, Drieu K. Ginkgo biloba extracts and cancer: a research area in its infancy. Fundam Clin Pharmacol. 2003; 17: 405-17.

9. Wang CG, Dai Y, Li DL, Ma KY. Ginkgo biloba leaf extract action in scavenging free radicals and reducing mutagenicity and toxicity of cigarette smoke in vivo. J Environ Sci Health Part A: Toxic/Hazard Subst Environ Eng. 2010; 45: 498-505.

10. Kuribara H, Weintraub ST, Yoshihama T, Maruyama Y. An anxiolytic-like effect of Ginkgo biloba extract and its constituent, ginkgolide-A, in mice. J Nat Prod. 2003; 66: 1333-7.

11. Satyan K, Jaiswal A, Ghosal S, Bhattacharya S. Anxiolytic activity of ginkgolic acid conjugates from Indian Ginkgo biloba. Psychopharmacology. 1998; 136: 148-52.

12. Dennehy C. Botanicals in cardiovascular health. Clin Obstet Gynecol. 2001; 44: 814-23.

13. Mahady GB. Ginkgo biloba for the prevention and treatment of cardiovascular disease: a review of the literature. J Cardiovasc Nurs. 2002; 16: 21-32.

14. Zhou W, Chai $\mathrm{H}$, Lin $\mathrm{PH}$, Lumsden $\mathrm{AB}$, Yao $\mathrm{Q}$, Chen C. Clinical use and molecular mechanisms of action of extract of Ginkgo biloba leaves in cardiovascular diseases. Cardiovasc Ther. 2004; 22: 309-19.

15. Shankar PK, Kumar V, Rao N. Evaluation of antidiabetic activity of ginkgo biloba in Streptozotocin induced diabetic rats. Iran J Pharmacol Ther. 2005; 4: 16-9.

16. Chen S-H, Liang Y-C, Chao JC, Tsai L-H, Chang C-C, Wang C-C, et al. Protective effects of Ginkgo biloba extract on the ethanol-induced gastric ulcer in rats. World J Gastroenterol. 2005; 11: 3746.

17. Shankar PK, Kumar V, RAO N. Evaluation of antidiabetic activity of Ginkgo biloba in streptozotocin induced diabetic rats. Iran J Pharmacol Ther. 2005; 4:

18. Ellnain-Wojtaszek M, Kruczyński Z, Kasprzak J. Investigation of the free radical scavenging activity of Ginkgo biloba L. leaves. Fitoterapia. 2003; 74: 1-6.

19. Galluzzi S, Zanetti O, Binetti G, Trabucchi M, Frisoni GB. Coma in a patient with Alzheimer's disease taking low dose trazodone and ginkgo biloba. J Neurol Neurosurg Psychiatry. 2000; 68: 679-80.

20. Canevelli M, Adali N, Kelaiditi E, Cantet C, Ousset P-J, Cesari M. Effects of Gingko biloba supplementation in Alzheimer's disease patients receiving cholinesterase inhibitors: data from the ICTUS study. Phytomedicine. 2014; 21: 888-92.

21. Chen Q, Liang J. Effects of ginkgo biloba extract on the production performance and serum biochemical indexes of broilers. Feed Res. 2013: 47-9.

22. Qichun H, Xiaoyan Y, Shuhui L, Yuqin H, Yan L. Effects of Ginkgo Biloba Extract on Lymphocyte Proliferation and the Level of Cytokines in Broiler Chicks. Chin Agric Sci Bull. 2012; 28: 23-6.

23. Li $\mathrm{z}$, Wang L. Effect of ginkgo leaves extract to immune performance in broiler. Heilongiang xu mu shou yi. 2014; 5: 98-9.

24. Zhang X, Cao F, Sun Z, Yu W, Zhao L, Wang G, et al. Effect of feeding Aspergillus niger-fermented Ginkgo biloba-leaves on growth, small intestinal structure and function of broiler chicks. Livest Sci. 2012; 147: 170-80.

25. Cao F, Zhang X, Yu W, Zhao L, Wang T. Effect of feeding fermented Ginkgo biloba leaves on growth performance, meat quality, and lipid metabolism in broilers. Poult Sci. 2012; 91: 1210-21.

26. Zhao L, Zhang X, Cao F, Sun D, Wang T, Wang G. Effect of dietary supplementation with fermented Ginkgo-leaves on performance, egg quality, lipid metabolism and egg-yolk fatty acids composition in laying hens. Livest Sci. 2013; 155: 77-85.

27. Zhou H, Wang C, Ye J, Chen H, Tao R. Effects of dietary supplementation of fermented Ginkgo biloba L. residues on growth performance, nutrient digestibility, serum biochemical parameters and immune function in weaned piglets. Anim Sci J. 2015; 86: 790-9.

28. Salgado JM, Abrunhosa L, Venâncio A, Domínguez JM, Belo I. Enhancing the bioconversion of winery and olive mill waste mixtures into lignocellulolytic enzymes and animal feed by Aspergillus uvarum using a packed-bed bioreactor. J Agric Food Chem. 2015; 63: 9306-14

29. Carraturo A, Raieta K, Tedesco I, Kim J, Russo GL. Antibacterial Activity of Phenolic Compounds Derived from Ginkgo biloba Sarcotestas against Food-Borne Pathogens. Br Microbiol Res J. 2014; 4: 18-27.

30. Tomás-Lorente F, Iniesta-Sanmartín E, Tomás-Barberán FA, Trowitzsch-Kienast W, Wray V. Antifungal phloroglucinol derivatives and lipophilic flavonoids from Helichrysum decumbens. Phytochemistry. 1989; 28: 1613-5.

31. Tao R, Wang C-Z, Kong Z-W. Antibacterial/antifungal activity and synergistic interactions between polyprenols and other lipids isolated from Ginkgo Biloba L. leaves. Molecules. 2013; 18: 2166-82.

32. Wang J, Cao F, Su E, Wu C, Zhao L, Ying R. Improving flavonoid extraction from Ginkgo biloba leaves by prefermentation processing. J Agric Food Chem. 2013; 61: 5783-91.

33. General Administration of Quality Supervision IaQotPsRoC, China SAotPsRo. Determination of feed cellulase activity. Filter paper assay method. Beijing: China Zhijian Publishing House. 2009; 5p.

34. Miller GL. Use of dinitrosalicylic acid reagent for determination of reducing sugar. Anal Chem. 1959; 31: 426-8.

35. Zhang S, Xu S, Wang Y. Food sensory analysis and experiment. Beijing: Chemical Industry Press; 2006.

36. Guarda A, Rosell C, Benedito C, Galotto M. Different hydrocolloids as bread improvers and antistaling agents. Food Hydrocoll. 2004; 18: 241-7. 
37. Bradstreet RB. Kjeldahl method for organic nitrogen. Anal Chem. 1954; 26: 185-7.

38. Bouterfas K, Mehdadi Z, Aouad L, Elaoufi M, Khaled M, Latreche A, et al. Does the sampling locality influence on the antifungal activity of the flavonoids of Marrubium vulgare against Aspergillus niger and Candida albicans? J Mycol Med. 2016; 26: 201-11.

39. Zhou $\mathrm{H}$, Wang C-Z, Ye J-Z, Chen H-X, Tao R, Zhang Y-S, Solid-state fermentation of Ginkgo biloba L. residue for optimal production of cellulase, protease and the simultaneous detoxification of Ginkgo biloba L. residue using Candida tropicalis and Aspergillus oryzae. Eur Food Res Technol. 2015; 240: 379-88.

40. Tan RX, Zou WX. Endophytes: a rich source of functional metabolites. Nat Prod Rep. 2001; 18: 448-59.

41. Zhang X, Zhao L, Cao F, Ahmad H, Wang G, Wang T. Effects of feeding fermented Ginkgo biloba leaves on small intestinal morphology, absorption, and immunomodulation of early lipopolysaccharide-challenged chicks. Poult Sci. 2013; 92: 119-30.

42. Bhat MK. Cellulases and related enzymes in biotechnology. Biotechnol Adv. 2000; 18: 355-83.

43. Yu X, Liu Y, Cui Y, Cheng Q, Zhang Z, Lu JH, et al. Measurement of filter paper activities of cellulase with microplate-based assay. Saudi J Biol Sci. 2016; 23: S93-8.

44. Xiao Z, Storms R, Tsang A. Microplate-based filter paper assay to measure total cellulase activity. Biotechnol Bioeng. 2004; 88: 832-7.

45. Rowin J, Lewis SL. Spontaneous bilateral subdural hematomas associated with chronic Ginkgo biloba ingestion. Neurology. 1996; 46: 1775-6.

46. Mateos E, González JM. Biomass: potential source of useful energy. Cellulose. 2007; 1: 559-63.

47. Boisen S, Hvelplund T, Weisbjerg MR. Ideal amino acid profiles as a basis for feed protein evaluation. Livest Prod Sci. 2000; 64: 239-51.

48. Huynh NT, Van Camp J, Smagghe G, Raes K. Improved release and metabolism of flavonoids by steered fermentation processes: a review. Int J Mol Sci. 2014; 15: 19369-88.

49. Pandey A, Soccol CR, Mitchell D. New developments in solid state fermentation: I-bioprocesses and products. Process Biochem. 2000; 35: 1153-69.

50. Coleman SW, Moore JE. Feed quality and animal performance. Field Crop Res. 2003; 84: 17-29.

51. Morrill J, Dayton A. Effect of Feed Flavor in Milk and Calf Starter on Feed Consumption and Growth1. J Dairy Sci. 1978; 61: 229-32.

52. McFeeters R. Fermentation microorganisms and flavor changes in fermented foods. J Food Sci. 2004; 69.

53. Cheng H, Qin Z, Guo X, Hu X, Wu J. Geographical origin identification of propolis using GC-MS and electronic nose combined with principal component analysis. Food Res Int. 2013; 51: 813-22.

54. Wang M, Zeng L, Lu S, Shao M, Liu X, Yu X, et al. Development and validation of a cryogen-free automatic gas chromatograph system (GC-MS/FID) for online measurements of volatile organic compounds. Anal Methods. 2014; 6: 9424-34

55. Bosset J-O, Gauch R. Comparison of the volatile flavour compounds of six European 'AOC'cheeses by using a new dynamic headspace GC-MS method. Int Dairy J. 1993; 3: 359-77.

56. Chen $\mathrm{S}$, Xing X-H, Huang J-J, Xu M-S. Enzyme-assisted extraction of flavonoids from Ginkgo biloba leaves: improvement effect of flavonol transglycosylation catalyzed by Penicillium decumbens cellulase. Enzyme Microb Technol. 2011; 48: 100-5.

57. Schuster E, Dunn-Coleman N, Frisvad J, Van Dijck P. On the safety of Aspergillus niger-a review. Appl Microbiol Biotechnol. 2002; 59: 426-35.

58. Schaafsma G. The protein digestibility-corrected amino acid score. J Nutr. 2000; 130: 1865S-7S.

59. Wu G. Dietary requirements of synthesizable amino acids by animals: a paradigm shift in protein nutrition. J Anim Sci Biotechnol. 2014; 5: 34. 